\title{
РЕЦЕНЗІЯ НА НАВЧАЛЬНИЙ ПОСІБНИК
}

\section{«НАНОХІМІЯ ТА НАНОТЕХНОЛОГÏ̈ऽ ТЕРЕБІЛЕНКО К. В., ОГЕНКА В. М.}

\section{П. Г. Нагорний}

Київський національний університет імені Тараса Шевченка, хімічний факультет, Київ 01601, вул. Льва Толстого, 13

*e-mail:pnagorny@ukr.net

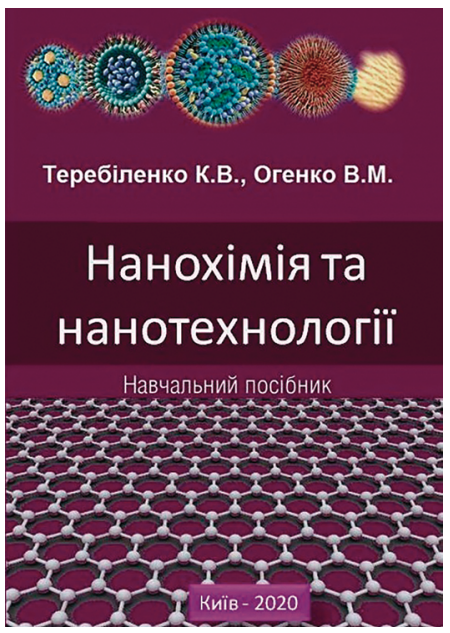

Анотація. Надано рецензію на навчальний посібник «Нанохімія та нанотехнології» для студентів хімічних спеціальностей базового комплексу знань, який націлено на формування у студентів можливостей для вирішення фахових завдань та поглибленого аналізу проблем сучасних наноматеріалів для новітньої техніки. Автори дають чіткі визначення наукових термінів, які застосовують як у світовій літературі, так і у вузькоспеціалізованих напрямках досліджень. Розробниками посібника узагальнено та систематизовано теоретичні надбання у сфері класифікації, методів одержання, стабілізації та застосування різноманітних наноструктурованих матеріалів. Посібник із дисципліни «Нанохімія та нанотехнології» відповідає вимогам щодо підготовки навчальної літератури для магістрів хімічного факультету, містить сучасну, гарно структуровану та чітко викладену інформацію, що $є$ основою для комплексної та грунтовної підготовки фахівців у галузі хімії.

Ключові слова: нанохімія, нанотехнології, квантові точки, фулерен, графен.

Рушійною силою сучасних наукових досягнень $є$ тяга до відкриття нових таємниць матерії та використання отриманих здобутків на благо суспільства. Найбільшу увагу науковців на сьогодні прикуто до наноматеріалів та наночасточок, адже саме завдяки нанохімії та нанотехнологіям відбувається прогрес у мініатюризації приладів, сенсорів та матеріалів, відкриваються нові сфери застосування наноелектроніки, фотоніки, оптики та інших важливих наукоємних напрямків.

Навчальний посібник «Нанохімія та нанотехнології» націлено на формування у студентів хімічних спеціальностей базового комплексу знань із нанохімії та нанотехнологій для вирішення фахових завдань та поглибленого аналізу проблем сучасних 
наноматеріалів для новітньої техніки, що і $€$ метою вивчення зазначеної навчальної дисципліни.

Посібник складено відповідно до програми навчальної дисципліни, він містить теоретичний матеріал, короткі висновки для узагальнення, питання для самоконтролю, задачі та завдання для самостійного розв'язку і список рекомендованої літератури. Представлений посібник складається зі вступу, 4-х розділів, а його структура дозволила авторам детально розглянути різні аспекти нанохімії: від класифікації до застосування вуглецевих наносистем, квантових точок, оксидних та металічних наноструктур. Перевагою цього посібника $\epsilon$ те, що автори дають чіткі визначення наукових термінів, які застосовують як у світовій літературі, так і у вузькоспеціалізованих напрямках досліджень. Це виключає можливість тлумачень, зумовлених різним розумінням одних і тих самих термінів. У посібнику визначено основні принципи та інструментарій нанохімії як науки, розглянуто взаємозв'язок «склад - будова дисперсність - властивості» у світлі сучасних металічних, оксидних та вуглецевих наноматеріалів.

Розробниками посібника узагальнено Й систематизовано теоретичні надбання у сфері класифікаціі, методів одержання, стабілізації та застосування різноманітних наноструктурованих матеріалів. Запропонована послідовність викладення теоретичного матеріалу гарно ілюстрована, містить велику кількість схем, рисунків та таблиць, що неодмінно покращує сприйняття матеріалу та створює умови для логічного засвоєння змісту дисципліни. Питання, що розкривають сутність відпо- відних тем, забезпечують викладення методологічних основ дисципліни «Нанохімія та нанотехнології».

У першому розділі посібника окреслено галузі застосування наноматеріалів та історичний аспект становлення нанохімії як науки. Особливо мотиваційно виглядає таблиця з лауреатами Нобелівської премії, які внесли вагомий вклад у розвиток дослідження наносвіту.

У другому розділі (с. 29-76) детально показано основні аспекти синтезу наносистем як із газової фази та розчинів, так i масштабних промислових виробництв. Відмінною рисою є вперше продемонстровані можливості зеленої хімії на шляху дизайну та виготовлення нанокомпозитів та наноматеріалів.

Одну 3 найважливіших підвалин у нанохімії займають вуглецеві матеріали, яким присвячено третій розділ посібника (с. 77-129), причому завдяки авторському вкладу всесвітньовідомого спеціаліста в області графену та вуглецевих квантових точок Огенка Володимира Михайловича, який вперше озвучив початок «графенової революції, вдало окреслено не тільки шляхи синтезу карбонових наноалотропів, а й їхню проблематику застосування.

Загалом навчальний посібник спрямовано на поглиблене вивчення найбільш типових підходів до синтезу наноматеріалів, методів їхньої класифікації, дослідження їніх властивостей, опанування студентами найновіших даних у галузі нанохімії та нанотехнологій. У використаній літературі зазначено чимало оглядів у високорейтингових журналах, проведено докладний аналіз сучасної англомовної літератури в цій галузі. 
Рецензований навчальний посібник 3 дисципліни «Нанохімія та нанотехнологій» відповідає вимогам щодо підготовки навчальної літератури для магістрів хімічного факультету, містить сучасну, гарно структуровану та чітко викладену інформацію, що $є$ основою для комплексної та грунтовної підготовки фахівців у галузі хімії. Безперечно, посібник буде цікавим не тільки для студентів, а й для аспірантів та молодих науковців, які переймаються сучасними досягненнями нанотехнологій на найвищому науковому рівні.

\section{REVIEW OF THE TEXTBOOK}

"NANOCHEMISTRY AND NANOTECHNOLOGIES" TEREBILENKO K. V, OGENKO V. M

\section{P. G. Nagorny}

Taras Shevchenko National University of Kyiv, Faculty of Chemistry, Kyiv, 01601, Leo Tolstoy Str., 13

*e-mail:pnagorny@ukr.net

Keywords: nanochemistry, nanotechnology, quantum dots, fullerene, graphene.
A review of the textbook «Nanochemistry and nanotechnology» for students of the chemical specialties of the basic set of knowledge, which aims ape to form opportunities of the students to solve professional problems and in-depth analysis of modern nanomaterials for the latest technologies. The authors give clear definitions of scientific terms that are used in both the world literature and in highly specialized areas of research. The developers of the manual summarize and systematize the theoretical achievements in the field of classification, methods of obtaining, stabilizing and using various nanostructured materials. The textbook on the subject "Nanochemistry and Nanotechnology" meets the requirements for the preparation of educational literature for masters of chemistry, contains modern, well-structured and clearly stated information, which is the basis for comprehensive and thorough training of specialists in chemistry. The textbook is aimed at in-depth study of the most typical approaches to the synthesis of nanomaterials, methods of their classification, study of their properties, students' mastery of the latest data in the field of nanochemistry and nanotechnology. The literature used contains many reviews in high-ranking journals, a detailed analysis of modern literature in this area.

Стаття надійшла 12.06.19. 